\title{
Criminal Networks and Conflict-resolution Mechanisms in Northern Mali*
}

\author{
Kalilou Sidibé
}

Abstract Northern Mali faces three principle, intertwining security threats: trafficking, rebellious uprisings and terrorist activity. Any attempts at maintaining law and order are undermined by the fragility of state structures. These threats also weaken the socioeconomic fabric of local communities and Malian national and territorial unity. The Malian government endeavours to address these challenges by adopting and implementing security and anti-terrorism policies, as well as social and economic development programmes. External partners support the Malian government in its efforts through a variety of joint anti-terrorism and development policies aiming to strengthen the state's operational capacity in the region. Furthermore, local communities work alongside state actors in the development and securitisation of Northern Mali by employing traditional conflict-management mechanisms (intercommunity and interclan solidarity systems). This strategy may considerably reduce the risk of open conflict and contribute to the establishment of a multilevel shared governance system.

\section{Introduction}

Four armed rebellions, ${ }^{1}$ combined with droughts in $1973^{2}$ and 1984, have adversely affected Mali's socioeconomic development. The Tuareg rebellion started in the 1960s and gained momentum in the 1990s. The rebellions took the form of mobile commandos targeting paramilitary forces such as the gendarmerie, ${ }^{3}$ police, and the armed forces. Nomadic communities living in Northern Mali have been particularly impacted by the effects. These include the mass exodus of young people, illiteracy, fragile democratic achievements, and the political exploitation of intracommunity tensions. These are exacerbated by environmental factors, including the lack of rainfall and spread of the Sahara desert, degradation of the water table and decreasing cattle numbers. Insecurity has resulted in the absence of rule of law, in which, in addition to armed rebellions, trafficking in drugs, vehicles, weapons and cigarettes thrive. Further, the Sahel is turning into a launching pad for international terrorism, especially for $\mathrm{Al}$ Qaeda in the Islamic Maghreb (AQIM).

This study explores the causes and consequences of these developments from a sociological perspective. It elaborates on the three security threats (rebellions, trafficking, and terrorism), which affect the region, and provides a typology of criminal networks and existing terrorist groups, emphasising their interconnectedness and focusing on the impact of criminal activities and terrorist threats on local communities. The study also analyses the role of state and international actors in managing the crisis. Further, it addresses the role of non-state actors (local communities, non-governmental organisations (NGOs) and other social movements). It highlights the contribution of local community leaders (mainly customary chiefs and chefs de fractions), ${ }^{4}$ through the deployment of traditional mechanisms for conflict resolution, and the implementation of an alternative, networked, approach to security.

\subsection{The strategic context of Northern Mali}

1.1.1 Geography and sociology of Northern Mali

Northern Mali is made up of three regions, whose inhabitants make up 10 per cent of the national population: Timbuktu $(681,691$ inhabitants), Gao (544,120 inhabitants) and Kidal (67,638 inhabitants) (2009 population 
census). Malian communities living in the north of the country are nomadic: Tuaregs (1.7 per cent of the national population); Arabs, including Moors and Kountas (1.2 per cent of the national population); Peuls, nomadic pastoralists (data unavailable); and the Sonrhaïs or Songhoys, ${ }^{5}$ who live in fixed settlements ( 7.2 per cent). ${ }^{6}$ The Sonrhaïs are the largest community in the Timbuktu and Gao regions, followed by the Tuaregs, also called 'blue people' due to the colour of their clothing, who are predominant in the Kidal region. They can also be found in Ménaka and Bourème in the Gao region and around Timbuktu. Arabs are mainly found in Timbuktu, Bourème and Kidal. The Kountas inhabit the Telemsi valley, between Gao and Kidal. The nomadic Peuls are scattered around these three regions.

The Tuaregs, Arabs/Moors and Peuls share relatively similar physical traits (tall, slim, and generally fair), and differ from the black African features of Songhaï populations. The social organisation of these three communities is also very similar (highly hierarchical, caste-based, where authority is based on Islamic chieftaincy).

Despite sharing a common language, the Tuareg are not a homogenous group. They are divided into a number of sub-groups who live in different territorial entities. Social organisation among Tuaregs is highly hierarchical and sketchy (Bourgeot 1995). Social stratification is vertical, comprising: the noble class (Imajaggan), warrior tribes such as Ifoghas and Kel Haggar, merchant tribes, religious and intellectual elites (Ineslemen), vassal tribes (Imrad), artisans (Inaden, who are mainly blacksmiths), former Tuareg prisoners (Irawellan), freed slaves (Iklan) and slaves. Tuareg society is organised around powerful symbols such the war drum (ettabel), which symbolises power. The power holder, who bears the title of Amanukal, is the military leader, chosen by a deliberative assembly, made up of representatives of the most powerful families of dominant tribes (Tawshit). The Amanukal stands as supreme chief of the confederation of Tuareg tribes living within the premises of its political authority (Tisaradh). The Amanukal is a traditional chieftaincy with a matrilineal form of succession (Sidibé 2006). Tuaregs practice a liberal form of Islam, and power is based on social prestige and charisma (warrior virtues are highly regarded in Tuareg society), hence its secular essence.
Malian Arabs are made up of the Kounta, the Barabich, the Gouanin, the Shamba and the Rguiba (Moors). The Qabila (tribes) are mainly descendents of a common ancestry, which is the basis of its hierarchical social organisation. This is also the case among Moors such as the warriors (Hassan), religious elites (Zawaya), and tributaries (Znaga). Life is principally dominated by Islam. The Kounta are the leaders of the traditional chieftaincy and their power is essentially religious (some regard them as descendents of Prophet Mohammed).

The social organisation of the Peuls is hierarchical and complex. At the top the noble class are the Duroob (nomads) and the Jaawambe (advisors and assistants). The intermediary class is made up of artisans: Yneebè (caste-based artisans), wayilbe Baylo (blacksmiths), Lawbe, Labbo (carpenters), Sakkebe, Sakke (cobblers) and the Griot classes (Mabube and Mabo). The Wambabe and Banbado are adulators, musicians, and guardians of traditions. At the bottom of the pyramid are domestic servants (Maccube, Maccudo or Kordo). The supreme chief is elected by tribe leaders.

The Sonrhaïs or Songhaïs are both black and fair skinned, and principally thrive on agriculture and cattle rearing. Boubacar Séga Diallo describes it as hierarchical and conflictual, and divided into three groups: the Sorko Sonrhai (fishermen who are regarded as masters of the seas), the Do ou Gabibi (farmers and cattle farmers, whom are regarded as masters of the earth), and the Gow (hunters). These groups entertain conflicting relationships (Diallo 2007). In Sonrhaï society, the Askia are the ruling class. The noble class is made up of Zarma (the nobility) and Marabouts (holders of religious authority). Castes are composed of the Sorko Fono and Sorko Faran (fishermen, a sub-group of the Sorko Sonrhai). The bottom of the social ladder is made up of servants (tyindikata and gabibi, farming slaves; and the arbi and zanji, descendants of slaves). The Sonrhaïs have various symbols of power: the seal, the Koran, the turban, the green skullcap, the 12 banners, and the drum. The holder of political power bears the title of Askia. This power is essentially secular (Durand 1982: 227).

The relations between these four communities have long been characterised by conflict and rivalry. Before colonisation, intercommunity 
violence in Northern Mali consisted mainly of Tuareg raids on other communities and caravans of traders. Furthermore, clashes between nomadic populations (Arabs/Tuareg, Tuareg/Peuls) on the one hand, and with farming populations on the other, were frequent. Conflictual historical relations between 'white' populations (Tuaregs and Arabs) and black populations (farming communities) stem from superiority and/or inferiority complexes: white populations saw themselves as superior to their black counterparts. It is in this context that the latter (black populations), who saw themselves as legitimate owners of the land, took up arms against Tuareg and Arab communities. This led to deadly clashes as recently as 1995 (during the third Tuareg rebellion).

After colonisation, powerful Tuareg tribes such as the Ifoghas continued to wage war against other Tuareg tribes, and against Arab groups. Conflicts with the latter group pertained to control of the trans-Saharan trade. Frequent rivalries are also noted between Rguibat Arabs and Kounta Arabs. Again, this rivalry continues to be played out in the modern context of drug trafficking: Arab groups of Tilemsi kidnapped a Kounta chief, Baba Ould Sidi El Moctar, at Anefis in the Kidal region in January 2010, mainly in response to the capture of one of their drug cargos by the Ifoghas and the Kountas. He was subsequently released thanks to the intervention of Mali's president, Amadou Toumani Touré. Tensions between Tuaregs and Peuls, relating to cattle theft and grazing land, have led to several assassinations. Cattle farmers, the Peuls, and merchant Arabs accuse the Tuaregs of stealing cattle and behaving as if they are absolute masters of the northern territories.

Despite these conflicts, however, there are also instances of genuine intercommunity alliances, which are generally based on marriages and intercommunity cousinage, especially between the Tuaregs and Arabs. For instance, the Kountas are the traditional allies of Ifoghas Tuaregs of Kidal. They both claim to descend from the Prophet Mohammed.

\section{Security threats}

The Sahel has become the sanctuary of choice for criminal networks and terrorist groups searching for bases from which they can secure financing and plan attacks. Networks of traffickers thrive, partly because the region's vast and mountainous desert area is conducive to illicit activity.

\subsection{Criminal and terrorist networks}

2.1.1 Trafficking: arms, drugs, cigarettes, and vehicles In the north of the Sahel, arms traffickers favour several routes: in the Kidal region, the Kidal-TinEssako axis and the Tamassina valley-Tedjerert border with Algeria and Niger is popular; in the Timbuktu region arms are supplied through the Timbuktu border with Mauritania (Polisario axis).

Florquin and Pézard (2005:72) state that

Over the years the networks have been enriched, and affect other countries in the region (including the Mano River [countries on the West African coast]). To date, several routes are still used and contribute to the ongoing proliferation of arms in the north.

Local networks are linked to regional and international counterparts. For instance, Gèze and Mellah (2007) argue that the group, Groupe Islamique pour la Prédication et le Combat (GSPC Movement for Islamic preaching and combat) most likely bought weapons from Tuaregs in neighbouring countries.

More than 81,000 Kalashnikovs are estimated to be circulating in the Sahel. M16s used in the Chad conflict (2005-2010) were found in Mauritania; Beretta AR-70s used in the Lebanese civil war were seized when Algerian rebel groups operating in the border regions of Algeria, Mauritania, Mali, and Niger were captured. Small arms circulating in the Sahel include Israeli submachine guns, revolvers, automatic pistols, semi-automatic hunting rifles, assault rifles, heavy machine guns, mortars, hand grenades, grenade launchers, anti-air canons, anti-tank canons, and missile launchers (Izddine, cited in Hamadouch 2008). Almost every inhabitant carries a small arm. ${ }^{7}$ Armed robbery is common and populations use weapons to settle intercommunity disputes.

A transnational network of drugs trafficking is also well-established in Northern Mali. Some argue that tribal groups play a central role: 'No trafficking takes place without the association of local tribal groups. People involved in trafficking are therefore known by a good part of the population' (Antil 2010). For instance, there is a 
district of Gao called 'the cocaine district', referring to its residents. Some big villas on the main road leading to Kidal airport belong to wellknown drugs and cigarette traffickers. Residents can even identify the villas by their owners' area of trafficking (drugs, cigarettes or arms). Some complicity exists between the traffickers and certain populations (for instance young tribesmen with knowledge of the desert are used as drivers and guides). Some local state officials and civil servants are also 'actively complicit'. Members of the Kounta Arab communities, who control most trans-Saharan trade, are perceived to be the main actors in the drug trade.

Several other transnational actors are involved in drugs trafficking, especially the Sahraouis of the Polisario Front, Mauritanian 'businessmen' belonging to the Rguiba and Smacid tribes (influential and respected traders in Mauritania), elements of $\mathrm{Al}$ Qaeda in the Islamic Maghreb (AQIM), Algerians, Moroccans, and other international networks. ${ }^{8}$ Connections stretch to both the Moroccan mafia and Lebanese businessmen in the Canary Islands and in mainland Spain, as well as Galicians (Peduzzi 2010). The drug trafficking networks are organised such that one team in Northern Mali receives the merchandise from Latin America, and another team takes it on to Europe. Some of the regular armed forces and northern state officials are complicit.

Other trafficked goods are cigarettes and cars. Cigarette brands such as Marlboro, Gauloises, Legend and Gold Seal are sold at half the market price and flood Mali's main cities, including Bamako, Sikasso, Ségou and Kayes. Mauritania's capital Nouakchott is the main destination for luxury cars, particularly, from Europe and via Morocco. The Nouakchott- Nema-TimbuktuKidal route is the most used by mafia networks.

\subsubsection{Islamic terrorism}

In September 2006, four Islamist groups from the Sahel region, the Algerian Salafist Group for Preaching and Combat (Groupe Salafiste pour la Prédication et le Combat - GSPC), the Moroccan Islamic Combatant Group (Groupe Islamique Combattant au Maroc - GICM), the Libyan Islamic Combatant Group (Groupe Islamique Combattant Libyen - GICL) and the Tunisian Islamic Combatant Group (Groupe Islamique Combattant en Tunisie - GICT), along with other small Islamic groups from countries such as Mauritania, Mali and Niger, built an alliance with $\mathrm{Al}$ Qaeda. They subsequently renamed themselves Al Qaeda in the Islamic Maghreb (AQIM), and established a central command unit, with a view to their scope for action.

From supplying fighters to hotspots such as Iraq, Palestine and Afghanistan between 2004 and 2006, Islamic groups in the Maghreb became a united Salafist movement (Guidère 2008). The Sahel provides cover to train Jihadists from neighbouring countries and beyond. AQIM has taken advantage of the lack of state presence in the region to establish operations in various countries. Its operation covers thousands of kilometres from eastern Algeria to Mauritania's border with Senegal. The movement is currently made up of 200 to 800 highly mobile fighters. AQIM mainly recruits from amongst the Tuaregs, Arabs, and Moors because of their excellent knowledge of the desert. However, subSaharan Africans are also among the fighters.

Elements of AQIM have become increasingly present in cities of Northern Mali. However, according to a community leader who took part in the first negotiations to free Austrian hostages, there are also young people from the southern part of Mali among AQIM's fighters:

Surprised to see these young people among the terrorists, I enquired from one of them about their motivations for joining such a group. He pointed out that God has no colour and that it was more a matter of religious conviction' (interview, Bamako, 27 June 2011).

Religious indoctrination is widely practised in the south, and the radical Jihadist doctrine can appeal to unemployed young people.

These terrorist groups use various forms of trafficking to acquire vehicles, weapons, and effective means of communication. The transformation of the Sahara into a cocaine highway from Latin America allows AQIM to levy a tax on merchandise destined for Western countries. However, kidnappings of Western nationals have also become an important source of revenue. Sahelian Islamist groups have kidnapped and demanded ransoms for 30 people since 2003 (African Union 2010). In 2003, 32 European tourists were kidnapped near Illizi, 
Algeria, separated into two groups, and subsequently released in two phases. The first group was released on 13 May 2003, following a successful mission carried out by the Algerian army. The second group crossed the Sahara from West to East until the former Malian rebel leader Iyad Ag Aghali ${ }^{9}$ and the Malian authorities negotiated their release on 18 August 2003, after a ransom of about $€ 4.6$ million was paid (Bentaous 2004). An estimated 90 per cent of AQIM resources emanate from ransoms (reportedly US\$50 million) (El Watan 2010).

\subsubsection{The Tuareg rebellion}

The link established between the Tuareg rebellion and Islamic terrorism is more a matter of perception than evidence. The Tuareg rebellion started in the 1960s and effectively developed during the 1990s. The different waves of Tuareg rebellion pertain to the marginalisation of Tuareg and Arab nomadic communities. Successive Malian regimes dealt with the rebellions in different ways: between 1962 and 1964, the government of Modibo Keita militarily suppressed the rebellion. In 1990, the regime of General Moussa Traore also refused to negotiate with rebels, accusing them of being armed bandits.

However, the authorities which presided over the democratic transition of 1991 chose to recognise rebel movements. The Comité de Transition pour le Salut du Peuple (CTSP) started negotiations with the rebellion under the auspices of Algerian mediation in order to find a political solution to the issue.

This individual initiative by the president of the CTSP, Amadou Toumani Touré, was followed up by a technical steering group led by Baba Hakhib Haïdara, an influential person in Malian politics from Timbuktu, representing the northern regions. The report by two influential mediators, Mauritanian Ahmed Baba Miské and the French national Edgar Pisani, ${ }^{10}$ called for a deeper analysis of the situation in order to restore peace, and pointed to a number of obstacles to overcome. Former President Alpha Oumar Konaré, who won the 1992 elections, carried on with negotiations, leading to a peace treaty in 1996 (Pacte national), between the government and rebels. The search for a national solution led to the integration of former fighters into different branches of the army.
The treaty was also supposed to lay the foundations for Northern Mali's socioeconomic development (decentralisation, turning Kidal into a region, and the introduction of development projects and programmes). The Alliance Démocratique du 23 mai pour le Changement (ADC), led by Ibrahim Ag Bahanga brought the Tuareg issue back to the forefront of national debate in 2006. Following a long period of peace, some Tuareg officers attacked units of the national army in Kidal and Ménaka and made away with weapons and ammunition. They then declared a new rebellion against the government of Mali, which they accused of breaching the terms of the 1996 treaty.

This recurrence of the crisis can be explained by the persistent lack of development in the region, as well as weak state presence, especially in Kidal. Further, the Tuareg issue has always been exploited by neighbouring countries, such as Algeria and Libya under Qadafi. In fact, the Tuareg rebellion has always been played out in a context of regional rivalry and interference by Algeria and Libya. Most recently this encompasses regional positioning in the fight against terrorism in the Sahel, with each actor seeking to make themselves appear pivotal in the fight against AQIM.

Libya under Colonel Qadafi long encouraged Tuaregs to claim their autonomy. Elements of the 1990s rebellion were former fighters from the Libyan Islamic legion who fought in Chad, Palestine, Lebanon, and Nicaragua, returning with weapons and ammunition. ${ }^{11}$ Many rightly feared a resurgence of the Tuareg rebellion following turmoil in Libya: young Tuaregs were recruited to fight alongside forces loyal to Qadafi. However, the intensity of the North Atlantic Treaty Organisation (NATO) strikes forced many of these mercenaries back to Northern Mali, armed with weapons and ammunition. Qadafi played a key role in the resolution of the Tuareg issue, thus his death is likely to change the strategic context of the Sahel in a fundamental way.

Algeria has also always played an influential role in the Tuareg rebel movements, using them to fight against GSPC groups in the Sahel. Deadly fighting took place, for instance, between elements of the ADC and AQIM in Northern Mali. This led to the death of three main AQIM leaders, including El Para. ${ }^{12}$ According to reliable 
sources, this operation sought to reassure both Algerian authorities and international opinion that the Alliance had nothing to do with the Salafist movement. Many former rebels offered their services to fight against AQIM and to join a proposed specialised unit (unite special méhariste) which is supposed to maintain security in Northern Mali.

Furthermore, some leaders of the Tuareg rebellion are known to work for the Algerian secret services. This includes Deyti Ag Sidimo, an Arab from Tessalit. Despite his role, he also managed to become a special agent for the Libyans, which allowed him to be the interface between Tripoli and mercenaries from subSaharan Africa (Niangaly 2011). Algerian support for the Tuareg is to be situated within the context of rivalry with Libya. Algeria saw the establishment of a Libyan Consulate in Kidal as a plot between Mali and Libya, which would allow the latter to spy on them from Mali. Algeria had always been the interlocutor by default in the Tuareg issue, both in Mali and Niger. As such, its leaders did not take well to the Malian government's move to use a Libyan representative to instigate talks with $\mathrm{ADC}$ leader Ibrahim Ag Bahanga, who found exile in Tripoli.

\subsubsection{Three interwoven threats in the Sahel}

The three security threats described above feed into each other through a web of wellestablished connections. There is a strategic alliance between trafficking networks and terrorist groups which emanates from convergent interests: criminal networks benefit from violent actions perpetrated by terrorist and/or rebel groups, while the latter take advantage of the financing derived from criminal activities (Ammour 2009). AQIM terrorist groups use drug traffickers to obtain weapons, ammunition, $4 \times 4$ vehicles and communication tools (GPS and satellite phones) to carry out their activities. In order to remain elusive, elements of AQIM hand over the money received from ransoms to drugs traffickers who use it in their own activities. Fifty per cent of the profits generated from drug trafficking are paid back to AQIM in kind. ${ }^{13}$ In turn, AQIM provides security to drug convoys in the Sahel in return for substantial sums of money. ${ }^{14}$ This mutually beneficial connection was established after a round of cautious observation between these two criminal networks. In this regard, a well- informed observer speaks of 'hybridisation' to point out this convergence of interests between criminal networks and terrorist groups (interview, Bamako, 23 June 2011).

Independent groups of armed men also abduct Western nationals and 'sell' them on to AQIM a form of subcontracting. In June 2010 the Niger army clashed with a group of armed bandits on board three $4 \mathrm{x} 4$ vehicles, $80 \mathrm{~km}$ to the north of Arlit (an area rich in minerals, mainly exploited by the French company Areva). They seized 640 explosives, 435 detonators, and US $\$ 90,000$ left behind (Issa 2011).

\section{State actors and security threats}

The presence of criminal and terrorist groups in the north illustrates the difficulties the Malian state faces in exercising effective political control over its national territory. The availability of weapons in the area, the pursuit of easy money, the lack of an effective regional economic strategy and high youth unemployment only serve to fuel rebellions and undermine peace building. The illicit trans-Saharan trade and general criminality has forced Malian authorities to adopt an anti-terrorism/criminality policy in order to create an enabling environment for the sustainable development of these regions. The securitisation of the north is considered a categorical imperative. Mali's international partners are also involved in this fight.

\subsection{State responses}

The Malian government believes securitisation can only be achieved by deploying a two-pronged approach, which addresses both security and development issues.

\subsubsection{Strategies against security threats \\ Territorial administrative division}

Mali's regions are the administrative responsibility of governors, administrative areas are governed by prefects and urban districts are led by sub-prefects. Decentralised entities are governed by regional assemblies, area councils and district councils. District councillors are chosen through universal direct suffrage, and area and regional councillors through indirect suffrage. Leaders of fractions, villages, and urban districts work with local authorities. They are freely elected according to community customs, for life, except in cases of grave misconduct. The Malian state allows for the development and self- 
fulfilment of communities and local authorities on the condition that they subscribe to principles of the rule of law, national unity, and territorial integrity. The fragmentation of decision-making centres at local level has, however, reduced the role and moral influence of customary chiefs, chiefs of fractions and villages (Moussa 2005), reflecting the government's unease about their power. However, as one chef de fraction from the Kidal region noted:

Sidelining traditional chieftaincies has had [a negative] impact on conflict resolution in the north. Contrary to the former regime's practice of heavily involving chiefs of fractions and communities in the resolution of the crisis... during the 1990s, the current authorities prefer using the services of former rebel leaders (interview, Kidal, 16 May 2011).

The deployment of armed forces in the north of Mali In addition to its decentralised administrative authority, the state makes its presence felt through the deployment of security forces. The territorial distribution of security forces in the north is as follows: ${ }^{15}$

- Armed forces: there are an estimated 2,000 soldiers in the Gao region, 1,500 in Kidal and 1,700 in Timbuktu.

- The National Guard: the National Guard is a branch of the army entrusted with national security. One of its particularities is the creation of the specialised Meharist unit, which carries out operations on camel-back. Successors of the nomadic guard, Meharist units were incorporated into the National Guard in 1995, with the support of the French Cooperation, to cope with the lack of resources needed to control the vast desert areas. Many former Tuareg rebel fighters joined the Meharist units, after the peace accords. The National Guard has 400 soldiers in Gao, 350 in Kidal, and 450 in the Timbuktu region.

- The national gendarmerie: has 275 officers in the Gao region, 150 in the Kidal region, and 250 in the Timbuktu region.

- The national police: there are 79 officers in the Gao region, 46 in the Kidal region, and 27 in Timbuktu.

The relatively weak presence of armed and security forces in Northern Mali, reflected by low deployment numbers, is at odds with Malian authorities' desire to curb insecurity in the region. Arguably, the situation is due to the various peace negotiations with rebel movements, who demanded reduced military presence in the north. The governor of Kidal also underlined the fact that security personnel assigned to the region rarely take up their posts because of the difficult geographic and climatic conditions.

Legislative instruments

In July 2008, Mali adopted law no. 08-025, pertaining to the prevention of terrorist acts, comparable to laws adopted by the Council of Europe and the European Union. It criminalises acts which can lead to the perpetration of terrorist offences such as public provocation, incitement to commit terrorist acts and terrorist recruitment. This law is in line with the United Nations' global anti-terrorism strategy.

Moreover, the government has introduced an integrated programme against drugs trafficking and organised crime. New anti-crime structures including Pôles économiques and the Office National de Répression du Trafic de Drogue et de Stupéfiants have been created. The programme is supported by bilateral donors, including Denmark, Luxembourg, Austria and Italy, through the United Nations Office of Drugs and Crime (UNODG).

The effectiveness of the fight against terrorist and criminal networks depends on close cooperation with other states in the region. Important differences in preferred strategies prevail, however. For instance, there is no transnational consensus on the issue of ransom payments. Algeria has always adopted a hard-line policy and refuses to negotiate with terrorists, and has always regarded Mali's willingness to do so as lax. Mauritania and Niger hold the same stance as Algeria. In contrast, Malian authorities have chosen to place emphasis on the lives of hostages. The Malian state has sought to avoid confrontation with terrorist groups based on an official belief that the country has never been the target of terrorists. This attitude has earned the government much criticism from its neighbours, especially Algeria.

However, a change in Mali's anti-terrorism strategy appears to be underway. Since the appointment of a new head of the Ministry of Foreign Affairs and International Cooperation, Mali is beginning to show some interest in 
cooperating with its neighbours and refusing to give in to AQIM's demands following recent kidnappings in Niger, where France opted for a military option to free hostages. This approach was unsuccessful, however: two French hostages were killed and AQIM managed to escape with the remaining hostages and disappeared in the Malian desert (Diarra, B.S. 2011; Charlet 2011; Diarra, A. 2011).

In the thrust towards this new policy stance, army chiefs from Mali, Algeria, Mauritania, and Niger met in Bamako on 29 April 2011 under the auspices of the new Minister for Foreign Affairs. This resulted in the creation of a joint operational committee (Comité d'Etat Major Opérationnel Conjoint - CEOG) to coordinate combined anti-terrorism military operations. For instance, since June 2011, the Malian army and its Mauritanian counterpart have cooperated in a new offensive against AQIM positions on their mutual border.

\subsubsection{Development policy for Northern Mali}

The Malian government's development policy framework for the northern regions is based on awareness-raising and supporting local communities to meet their basic needs and access basic social services, strengthening small arms return programmes and fighting against their proliferation. ${ }^{16}$

The main strategic directions of the security and anti-terrorism programme in Northern Mali are integrated into two local development programmes: The Emergency Programme for Security and Anti-terrorism in the North of Mali (Programme d'Urgence pour la Réduction de l'Insécurité et la lutte contre le Terrorisme dans le Nord-Mali PIRIN 2010-2012) and the Special Programme for Peace, Security and Development in the North (Programme Spécial pour la Paix, la Sécurité et le Développement dans le Nord-PSPSDN), created in 2010. PIRIN aims to eliminate the causes of insecurity in Northern Mali. The action plan focuses on the construction or renovation of barracks, the establishment of new security outposts, gendarmerie brigades and police stations, and infrastructure development (health centres, schools, boreholes, administrative offices, and tied accommodations). Particular emphasis is being placed on the development of the penal system, communication, and demilitarisation through the return of small arms. The PSPSDN has five dimensions: security, communications, governance, development, and management. The two programmes are complementary, although the PIRIN is more geared towards securitisation and the PSPSDN is mainly focused on local communities.

\subsection{International responses}

The presence of AQIM in the Sahel represents a global threat against which international partners are helping Mali to fight. International responses have consisted of the adoption of multilateral legal instruments, and the promotion of development and anti-terrorism policies which seek to strengthen states' operational capacity.

\subsubsection{International legal instruments against terrorism}

There are at least 16 international conventions that can be classed as global anti-terrorism instruments (see UNODG 2009). Regional prevention and suppression instruments have also been signed at regional level, mainly the Convention of the African Union (AU) on the prevention and fight against terrorism, adopted at Addis Ababa on 8 July 2004.

Africa counts two main terrorist groups affiliated to Al Qaeda: AQIM in the Sahel and Al Shabab and Aalamia in the East. The African Union has called for a prohibition of ransom payments to terrorist groups, the elaboration of an Africaspecific law on terrorism and the nomination of an AU Special Representative to coordinate antiterrorism programmes. An African Centre for Study and Research on Terrorism has been established to stand as the central point for information, research and analysis.

At the sub-regional level, the West African Economic and Monetary Union (WAEMU) has strongly committed to suppressing terrorism in its eight member states. It has adopted a number of pertinent measures such as Regulation No. $14 \backslash 2002 \backslash \mathrm{CM} \backslash W A E M U$ related to the freezing of funds and other financial resources and Guideline No. 04|2007|CM|WAEMU related to the fight against terrorist financing in its member states. Further, the Economic Community of West African States (ECOWAS) has begun to elaborate on a regional framework. ECOWAS seeks to provide the region with monitoring, intelligence gathering, analysis and dissemination capacities, and to fight against the presence and development of terrorist activity in West Africa (UN 2010a; Ipe, Cockayne and Millar 2010). 


\subsubsection{Military and development cooperation}

AQIM tends to attack Western interests, including business operations and diplomats, and has declared war on political leaders of countries in the region accused of corruption and allegiance with the West (and the USA in particular).

Individuals are also targeted by the Jihadists.

Algeria, which sees itself as the regional leader in the fight against terrorism in the Sahel, prefers partnership between Sahelian states, to Western intervention. This, according to Algiers, is to avoid turning the Sahel into another Afghanistan. Accordingly, the (unsuccessful) 2010 FrancoMauritanian intervention in Mali, wherein a commando of French Special Forces accompanied the Mauritanian army on a mission to free a French hostage from Al Qaeda, was not well received by Algeria. To avoid such future interventions, Algeria is encouraging coordination of intelligence services and the establishment of a common operations command.

The USA has supported Mali by providing training to local forces. Since 2002, Americans have helped develop the Pan-Sahel Initiative, which became the Trans-Sahara Counter Terrorism Initiative (TSCTI) in 2005. This plan aims to support the seven countries which border the Sahara in their fight against terrorism, under the direction of the United States Africa Command (AFRICOM), based in Stuttgart (Germany).

France also supports Mali’s fight against terrorism and drugs trafficking, mainly through its diplomatic representation, the delegation of the Home Security Service (Délégation du Service de la Sécurité Intérieure - SSI), and the Mission for Military and Defence Cooperation (Mission de Coopération Militaire et de Défense - MCMD). The SSI provides training and logistical support to national security (police, gendarmerie, civil security) and customs services. Training is related to drugs trafficking, document fraud, public order, forensics, and police intelligence. SSI also implements long-term programmes aimed at supporting Malian services in the fight against organised crime.

MCMD is composed of ten advisors and instructors deployed to various branches of the army. Its activities include providing equipment to the National Guard, technical and logistical support and organisational training.
The European Union is also an important actor and has developed multifaceted partnerships with countries of the Sahel. Its three principles of intervention relate to: threats to the EU's internal security (illegal immigration, drugs trafficking, and terrorism); protection of national and European investments; and supporting countries in the region to achieve the Millennium Development Goals. Three principles for action follow: ideological decontamination; demilitarisation of anti-terrorist strategies; and the decompartmentalisation of actions and initiatives.

The UN is also involved in this fight against organised crime and terrorism in the Sahel. The Governance, Peace, and Security Programme is a joint initiative of the government of Mali and the United Nations Development Programme (UNDP), with financial support from Switzerland and Luxembourg. An important aspect of this programme is the establishment of a community police force in the northern regions of Mali. The basic premise of the programme, according to its coordinator, Zéini Moulaye, is based on the principle of alternative policing. It seeks to allow local communities to take charge of their own security. It consists of deploying community police in each district. It also provides a role for customary and traditional authorities in security provision. It prioritises community involvement in the form of neighbourhood watch brigades and ensuring local access to information and communication, including translating administrative and legal documents into local languages and meetings between authorities, local representatives, security and armed forces and local communities (Moussa 2005; Ministère de la Sécurité Intérieure et de la Protection Civile 2005).

Alternative security seeks to bring together various stakeholders in the security domain (public authorities, civil society, the private sector, local representatives, local communities, and technical and financial partners). However, while Malian actors have adopted this concept in principle, it has yet to be fully implemented.

\section{Local communities and security threats}

Local communities, traditional leaders, opinion leaders, religious leaders, and local civil society organisations are all involved in responding to criminal and terrorist threats in Northern Mali. 
Residual insecurity threatens traditional ways of life for communities who depend essentially on cattle-rearing and trading across the Sahara.

\subsection{Impact of criminal threats and perceptions of local communities}

Communities living in Northern Mali are considered to be both the victims of the army's efforts to track down criminals and terrorists, and accomplices of rebellions, trafficking and Islamic terrorist activity. The way local communities perceive these threats is ambiguous, and can influence local responses to the security issue.

\subsubsection{The impact of security threats on local communities}

The social cohesion and the livelihoods of local communities in Northern Mali are greatly affected by recurrent security threats. This chronic insecurity impacts severely on tourism, the local crafts industry and cattle-rearing. Attacks perpetrated against aid workers and vehicle thefts keep tourists away. Businesses involved in the tourism industry (travel agents, hotels, vehicle hire companies, etc.) and local craftsmen are struggling to pay their employees, taxes and loans. Tradespeople suffer. Investments in the tourism sector have decreased and development projects have been halted.

Tensions arising from the disputes over the use of grazing pastures, cattle thefts and army incursions have severely impacted cattle-rearing. Cattle farmers are increasingly moving towards the south of Mali (to the regions of Mopti, Ségou and Sikasso for example). The proliferation of weapons has heightened insecurity and forced many people to move to cities, where they struggle to find work.

Others, including the Tuaregs, increasingly engage in illegal activity. The dividends of criminal activities (terrorism and drug trafficking) create tensions between communities in the North, most notably between the Tuaregs and the Arabs, and the Sonrhaï and the nomads. In order to consolidate their position, terrorists and criminals co-opt local communities and fractions by involving them in their activities. Local tribes profit greatly from their involvement, making it extremely difficult and challenging to control criminal and terrorist movements. Terrorist groups use many young Tuaregs and Arabs as informants. Traffickers also exploit young people's knowledge of the terrain. Some young Tuaregs are armed and act as couriers, earning considerable amounts. For example, a courier transporting drugs from Kidal to Agadès in Niger can make a few million CFA (Communauté de Francs Africain).${ }^{17}$ Until recently, young people restricted themselves to transporting the drugs, but traditional leaders are increasingly reporting drug use among young people in their community. Some local representatives are also reportedly being co-opted by drug traffickers.

Similarly, young people are prey to terrorist networks and religious fundamentalist groups. AQIM groups recruit local fighters by offering them money, while other groups brainwash youngsters into joining their ranks. American and European army officials have always feared the mutation of pious Muslims into fundamentalist groups in the north of Mali. One example of this transformation is the Dawa group, which was created in the then-Indian province of Dhaka in the 1930s. The group's preachers, mainly Pakistanis and Bengalis, spread their vision of Islam in Mali and neighbouring states. ${ }^{18}$ Its members belong to the popular Muslim movement Jama'at Tabligh and spend one year travelling to preach the principles of their movement. Their teachings have sown the seeds of a much more virulent and radical form of Islam in Mali. The Dawa group has even been linked to the GSPC (International Crisis Group 2005).

\subsubsection{Ambivalent local perceptions}

Populations in Northern Mali have mixed perceptions of terrorist and criminal threats. For most people, particularly in the Kidal region, the presence of 'so-called terrorists' is not a threat. One elected local representative remarked:

Al Qaeda in the Islamic Maghreb is not a jackal that is going to eat our cattle. AQIM does not threaten the population in any way. This means that communities don't see the need to protect themselves. However, communities do tend to protect development projects such as schools, madrasas, solar power stations, health centres, etc. People aspire to development and security. Nomads will get involved to protect these gains, and this is how we can prevent the recruitment of our young people by AQIM (interview, Timbuktu, 10 May 2011). 
But he also insists on the fact that 'Many nomads think that AQIM and fraud are legal activities. If you ask a nomad, he will tell you that he's a trafficker, fraudster or even a member of AQIM. For him, a trafficker is a tradesman' (ibid.).

For certain population groups, particularly the Tuareg community in Kidal, AQIM members are not terrorists. According to one fraction chief, 'AQIM is a force to be reckoned with in the region. They have money and they invest in projects such as building wells and providing healthcare to nomadic communities' (interview, Kidal, 16 May 2011). Army incursions, on the other hand, are often badly perceived. If the army intervenes to address an issue that affects the local community, such as weeding out armed bandits, then they are assisted by the local population. However, if the army acts to suppress trafficking and other illicit activity, then they become real enemies.

\subsection{The response of non-state actors}

In order to curb various threats, non-state actors rely on traditional conflict-resolution mechanisms. Further, the state calls upon these non-state actors to support the securitisation process in the region via a participatory governance approach.

\subsubsection{The mobilisation of traditional conflict-resolution mechanisms}

Sahelian communities, particularly the Tuareg, tend to be hierarchical, unequal and confrontational. Intercommunity rivalries exacerbate these inherent tensions. To overcome these challenges, communities have developed mechanisms and procedures to help prevent and resolve conflicts.

Traditions and customs play an important role in managing and resolving intercommunity conflicts. Konaté (2001) notes that many social practices and traditions across the region have contributed to and continue to play a part in maintaining social order today. Indeed, many communities across the region extol the virtues of tolerance and non-violence, as demonstrated by the expressions bamanan de sabali (invitation to moderation), bèn (harmony) and niongo gasi sigui (respecting others) commonly used in proverbs, songs and other stories. Peace building in these communities rests on the prevention of conflicts through social regulation and diplomacy. In most West African tribal societies, clans are interlinked through a system of solidarity and alliances that is key to social cohesion, and based on marriages between members of different clans, and the movement of cattle (akh idarren, inuf, tiyaten...) ; Sanakouya ('alliance à plaisanterie' in French, a system of common values amongst different clans/communities in Southern Mali based on good humour); Arkawel (being true to your word), Taboubicha (cousinage in French, or joking kinship); Achekk (respecting those weaker than yourself). These alliances between clans cement blood ties that reduce the risks of open conflict.

Communities in Northern Mali adopt similar traditional methods of conflict resolution, which are also based on the principles of Islam (prayers, Ramadan, Zakat), Sharia law (Koranic law and Hadiths from the Prophet Mohammed), and agreements. Community leaders, marabouts, and other wise men come together to resolve conflicts in a peaceful manner under the auspices of Islam, often presided over by the Cadi (leader of prayers and religious ceremonies, who applies Sharia if necessary). The Cadi is supported in his decisionmaking by traditional leaders and chiefs. Their moral authority contributes to the finality of decisions. For the Songhaïs, the marabout also plays the roles of Imam, judge, Cadi, professor, secretary and advisor. He is at the centre of conflict-resolution initiatives.

Local initiatives have started to emerge to educate communities about the various threats. Intercommunity meetings have been organised to raise people's awareness and to attempt to reestablish stability. These community leaders used the values of equality, solidarity, mutual help and understanding extolled by Islam to persuade opposing parties to seek peace and reconciliation. Examples of this include la rencontre de junhan, a local initiative to address the Tuareg issue in 1997, organised after the 1996 peace treaty, and efforts to mediate between the self-defence group Gandakoi and the Sonrhaïs in the north. Religious leaders have also intervened to resolve intercommunity conflicts, such as between the Arabs and Kountas in the Gao region.

In order to respond to terrorist threats in the north, the Malian government is now asking customary chiefs and leaders for their support. They are involved in hostage negotiations and are key spokespersons for the government in these discussions. However, when substantial ransoms 
are involved, community leaders tend to be superseded by former rebel leaders from the 1990s. The former rebels are closely linked to former Algerian GSPC members, who have now joined AQIM. Although their objectives were different, both groups used the desert as their base and were operational in the 1990s when the GSPC was fighting against the Algerian government and the Tuaregs the Malian government.

Notwithstanding the existence of communitybased conflict-resolution mechanisms, the insecurity issue jeopardises the very foundations of intercommunity solidarity. The Tuaregs hold the Arabs in general and the Kountas in particular responsible for drug trafficking, cigarette smuggling and car thefts in the region, while the Tuaregs are mostly responsible for the rebellious uprising. The Arabs are also thought to provide shelter to AQIM fighters. Both sides often seek revenge if a member of their community gets killed.

\subsubsection{The emergence of new networks: a form of participatory governance?}

The engagement of local communities in the northern regions (including parliamentarians, local elected representatives, fraction leaders, opinion leaders and senior executives) in implementing government policies is key to the region's response to its security issues. Various networks are involved in a multilevel governance framework aiming to build peace and bring security to the region. Most community leaders realise the seriousness of the threat for the entire sub-region, which exacerbates existing intercommunity tensions. For network leaders, AQIM are real terrorists who can strike anywhere at any time, including in Bamako.

Today, stakeholders involved in the response to security threats are organised and have developed networks of local leaders, state representatives and newly created local NGOs. An intercommunity meeting on peace and security in Northern Mali organised in Kidal in October 2009 brought together 1,432

participants from the three northern regions and Bamako. Participants included local elected representatives: national advisors, regional assembly presidents, mayors and municipal advisors; central government representatives in the regions: governors, prefects and sub-prefects; and customary leaders: local dignitaries, fraction chiefs and other local leaders. Every community in Northern Mali was represented, as well as the President of the 2006 Alger Agreement Monitoring Committee, the Directors of the Northern Development Agency and the National Investment Agency for Local Authorities, and Libyan and Algerian diplomats.

The forum led to the establishment of the Northern Mali Network for Peace and Security, supported by the European Union, which brings together individuals from different communities, fractions and professions. The Network is now the main point of contact for the Malian authorities and international partners. It acts as an interface between the government, local authorities, international partners and local communities. Since its inception, more than 360 fractions and villages have joined the network and a provisional secretariat has been set up, made up of 45 members. The Network's external partners are the Swiss Embassy in Bamako, the European Union and UNDP via the Shared Governance, Security and Peace Programme.

Further, a dynamic civil society is developing in Northern Mali, working to improve social cohesion, peace, and the rule of law. It comprises women's associations, youth organisations, associations of religious leaders and traditional chieftaincies. Civil society in Northern Mali is heavily involved in awareness-raising and education, particularly amongst nomadic communities. International NGOs are also present in the region.

\section{Conclusion}

The security situation in Northern Mali appears to be improving with the involvement of local communities in processes of conflictmanagement and the increased role of community networks, as well as the establishment of a community police force. The lack of means, combined with a weak security apparatus (police, gendarmerie, customs, and legal system), still constitute a major obstacle in the fight against these multiple threats, however. Some young people are distributing propaganda material, asking for the creation of a Tuareg state in the north of the country. Criminal activities such as drugs, weapons and cigarette trafficking continue to thrive. Elements of AQIM and other armed groups continue to operate from their Malian bases. 
Compounding these problems, armed groups have also taken advantage of the turmoil in Libya to acquire more weapons, ammunition, and state-of-the-art equipment in order to carry out their criminal activities and impose their hegemony in the region.

The 17 January 2012 rebellion, launched by le Mouvement National de Libération de l'Azawade (MNLA - the National Liberation Movement of the Azawade), is a logical extension of the existing tensions in Northern Mali. The arrival of Malian combatants from Libya has accelerated events but all the ingredients of the rebellion have been evident for some time. The

\section{Notes}

* This article was approved by the author on 20 March 2012 and therefore takes no account of the politically destabilising events that took place subsequently in Mali.

$\S$ Based on a paper translated from the French original by Marie-Anne Diedhiou-Roy.

1 1962-1964, 1990, 1994-1995 and 2006.

2 The drought of 1973 killed between 50,000 and 100,000 people. It caused a substantial decrease in production. Nomadic pastoralist groups such as the Tuareg lost almost half of their cattle.

3 Branch of the army with responsibility for law enforcement.

4 These fractions are administrative units. While urban districts in Mali are made up of area districts called quartiers, rural districts are made up of villages (in fixed settlements) or fractions (in nomadic areas). Each fraction is headed by a locally elected chief called chef $d e$ fraction, who plays the role of intermediary between the community and the state.

5 Sonrhaïs, Songhoys, Songhaïs are variations of the spelling.

6 Given the difficulties related to getting hold of reliable figures, we had to settle for data provided in the article, 'Population du Mali' (UN 2010b).

7 A significant factor of arms proliferation is their relative low cost. A Department for International Development (DFID) study on the causes of conflict in sub-Saharan Africa, noted, 'Everywhere in Africa, the usual price of the ever-present assault rifle AK 47 remains stable at 25 dollars' (DFID 2001: 15).

8 On 5 November 2009 a Boeing 727 from Venezuela, likely loaded with cocaine, was found
Malian government is now confronted with three problems: mass population displacement and the movement of refugees to neighbouring countries; upcoming elections (both presidential and a referendum on the new constitution); and a rapidly evolving military situation on the ground. The resolution of this new rebellion remains political. A military option, while potentially restoring calm, should not be viewed as the ultimate means of restoring peace to the region. Dialogue remains the most appropriate solution and there has been a discrete intervention from Malian civil society to restore peace in Northern Mali through mediation.

burnt on a makeshift runway in the desert in Gao region. In December 2009 Malian Police arrested a Spanish, a Portuguese and a Venezuelan man, who were suspected of involvement in the so-called 'Boeing de la Coke'. The suspects turned out to be closely linked to Mohamed Ould Didi, who was arrested in Mauritania in the same case (Peduzzi 2010).

9 Iyad Ag Aghali is the former leader of the rebellions of 1994 and 1995. He was the leader of the Alliance Démocratique du 23 mai pour le Changement, alongside Hassan Fagaga and Ibrahim Ag Bahanga. He is currently the Malian consul in Djeddah, Saudi Arabia.

10 Edgar Pisani, then Director of the Arab Institute, was not the French envoy. His mediation had been individually solicited by the Malian authorities.

11 Young Tuaregs called ishumar, are mainly unemployed youth who migrated to Libya from Northern Mali following the droughts of 1973 and 1984, as well as those who left to escape state repression of the 1962 rebellion.

12 Amri Saifi, also known as Abderazak El Para, was the leader of GSPC. He was arrested on 16 March in Tibesti by elements of the Mouvement pour la Démocratie et la Justice au Tchad (MDJT), a rebel movement against the authority of Ndjamena, Chad.

13 All community leaders were categorical on this aspect during our different interviews both in the north and in Bamako.

14 Interview with Alain Antil in the Malian daily Le Républicain, 6 July 2011.

15 Information obtained from documents obtained from the Gao Governorate and the national police in Bamako (2011), and supplemented by Kornio and Kebe (2008). 
16 Interview with Moctar Ouane, former minister of Foreign Affairs and International Cooperation of Mali in the daily Lindépendant of 28 September 2010.

17 Currency usable in Mali and in eight countries of West Africa: Benin, Burkina Faso,

\section{References}

African Union (2010) Report of the President of the Commission for the Reinforcement of Cooperation in the Prevention and Fight against Terrorism, $P S C / P R / 2$ (CCXLIX), 249th meeting of the Council for Peace and Security of the African Union, 22 November 2010

African Union (2002) Action Plan of the AU High Level Intergovernmental Meeting on Terrorism in Africa, Algiers, 11-14 September 2002

Ammour, L.A. (2009) 'Flux, Réseaux et Circuits de la Criminalité Organisée au Sahel et en Afrique de l'Ouest', Cahiers du CEREM spécial Sahel 13

Antil, A. (2010) Contrôler les Trafics ou Perdre le Nord, notes sur les Trafics en Mauritanie, Paris: Institut Français des Relations Internationales (IFRI)

Bentaous, A. (2004) 'Le Nord-Mali, Sanctuaire du Terrorisme et du Grand Banditisme' Quotidien d'Oran, 22 March, www.algeriawatch.org/fr/article/pol/us/nord_mali.htm (accessed 25 April 2012)

Bourgeot, A. (1995) Les Sociétés Touaregs, Étude Comparée: Mali-Niger, Paris: Karthala

Charlet, D. (2011) 'Niger: Impact des Balles sur les Otages Francais', $A F P$, 14 January

Department for International Development (2001) The Causes of Conflict in Sub-Saharan Africa, Working Paper, London: DFID

Diallo, B.S. (2007) l'Empire Songhoy, Bamako: Université de Bamako, www.histoireafrique.org (accessed 23 June 2011)

Diarra, A. (2011) 'Otages Français au Niger: L'un tué par le Raid, l'autre Exécuté par AQMI', le Quotidien Malien L'Indépendant 2674, 27 January

Diarra, B.S. (2011) 'Lutte Contre AQMI: Les 5 Péchés Capitaux de la France’, le Quotidien Malien Le Combat, 14 July

Durand, B. (1982) Histoire Comparative des Institutions, Nouvelles Éditions Africaines, Dakar

El Watan (2010) Blanchiment d'Argent du Terrorisme, de la Drogue et de la Contrebande: La Région de Tamanrasset sous haute Pression, El Watan, 12 October, www.elwatan.com/archives/rubrique .php?ed = 2010-10-12\&rub=ew:w:une:reportage (accessed 25 April 2012)
Côte I'voire, Guinea Bissau, Mali, Niger, Senegal and Togo.

18 They chose Northern Mali because of the widespread and long-standing tradition of marabouts, particularly in Timbuktu.

Florquin, N. and Pézard, S. (2005) 'Insurgency, Disarmament and Insecurity in Northern Mali, 1990-2004', in N. Florquin and E. Berman (eds), Armed and Aimless: Armed Groups, Guns and Human Security in the ECOWAS Region, Geneva: Small Arms Survey

Gèze, F. and Mellah, S. (2007) Al-Qaeda au Maghreb, ou la très Étrange Histoire du GSPC Algérien, Algeria Watch, 22 September, www.algeriawatch.com (accessed 25 April 2012)

Guidère, M. (2008) 'La Tentation Internationale d'Al-Qaïda au Maghreb', Focus Stratégique 12, Paris: Institut Français des Relations Internationales (IFRI)

Hamadouch, L.A. (2008) 'Entre Etats Faibles et Influences Extérieures', La Tribune, 29 April, www.algeria-watch.com (accessed 25 April 2012)

International Crisis Group (2005) Islam Terrorist in the Sahel: Fact or Fiction?, Africa Report 92, Geneva: International Crisis Group

Ipe, J.; Cockayne, J. and Millar, A. (2010) Implementing the UN Global Counter-Terrorism Strategy in West Africa, Centre on Global Counterterrorism Cooperation, www.globalct.org/ images/content/pdf/reports/West_Africa_ Report_Final.pdf (accessed 25 April 2012)

Issa, O. (2011) 'Après l'Accrochage entre les FDS et le Groupe de Bandis Armés, un ex Chef de Front Appréhendé', Le Républicain, 17 July

Konaté, D. (2001) Les Fondements Endogènes d'une Culture de Paix au Mali: Mécanismes Traditionnels de Prévention et de Résolution des Conflits, Paris: United Nations Educational, Scientific and Gultural Organisation (UNESCO)

Kornio, O. and Kebe, G. (2008) Projet d'Enquête Générale sur les Armes Légères et de Petit Calibre au Mali, rapport de réalisation, document, commission nationale de lutte contre la prolifération des armes légères, publié par la commission nationale de lutte contre la prolifération des armes légères, Bamako

Ministère de la Sécurité Intérieure et de la Protection Givile (2005) Etats Généraux de la Sécurité et de la Paix au Mali, Bamako

Moussa, A.I. (2005) Quelle Sécurité pour le Nord? Cas Spécifique de Kidal, Bamako: Friedrich Ebert Stiftung 
Niangaly, A. (2011) 'Aventure du Député de Tessalit, Deyti Ag Sidimo/Les Troubles Motifs d'une Rébellion', Le Prétoire, 25 July

Peduzzi, J. (2010) 'Physionomie et Enjeu des Trafics dans la Bande Sahélo-saharienne', Le Maghreb dans son Environnement Régional et International, Paris: Institut Français des Relations Internationales (IFRI), www.ifri.org/files/Afrique/Les_trafics_en Mauritanie_final.pdf (accessed 25 April 2012)

Le Républicain (2011) 'Un Expert Français sur le Trafic de Drogue au Sahel: "Des Hommes d'Etat, hauts Gradés et Proches de Président Impliqués ", 6 July

Sidibé, I.B.H. (2006) La Démocratie au Secours de la Sécurité: l'Expérience Malienne de la Gestion du Problème du Nord: Est-elle Transposable à d'autres Crises Africaines?, Centro Argentino de Estudios
Internacionales Programa Africa, www.caei.com.ar/es/programas/africa/02/.pdf (accessed 25 April 2012)

United Nations (2010a) Renforcer les Capacités dans le Domaine du Contre-terrorisme en Afrique de l'Ouest dans le Cadre de la Stratégie Globale de l'ONU Contre le Terrorisme, Seminar Working Paper, Abuja, 16-17 February 2010

United Nations (2010b) 'Population du Mali, official national statistics', United Nations Demographic Yearbook 2009-2010, www.un.org/ esa/population/unpop (accessed 25 April 2012)

United Nations Office on Drugs and Crime (2009) Handbook on Criminal Justice Responses to Terrorism, Vienna: UNODG, www.unodc.org/ documents/terrorism/Handbook_on_Criminal_ Justice_Responses_to_Terrorism_en.pdf (accessed 25 April 2012) 